\title{
EDUCAÇÃO DOMICILIAR NO BRASIL E GRUPOS DE APOIO: RESPOSTA À "FALTA DE SOCIALIZAÇÃO" FORA DA ESCOLA?
}

\section{Bruna Santos de Faria*, Luciane Muniz Ribeiro Barbosa}

\section{Resumo}

A pesquisa insere-se no contexto de análise do direito à educação no Brasil e as implicações que a escolha de famílias por não enviarem os filhos para a escola e ensiná-los em casa apresenta para a garantia de tal direito, com ênfase na socialização das crianças que não frequentam a escola. A pesquisa, de abordagem qualitativa, teve como objetivo principal realizar um mapeamento dos grupos locais de apoio às famílias brasileiras que optam pela educação domiciliar, bem como acompanhamento e análise da agenda de tais grupos, a fim de compreender se há preocupação em estabelecer atividades que propiciem a socialização das crianças que são ensinadas em casa. Além da revisão bibliográfica sobre a temática, foi realizado um levantamento, via redes sociais, dos grupos locais existentes, suas agendas e práticas divulgadas. A coleta e análise desses dados indicam que a maioria dos grupos locais de apoio à educação domiciliar promovem ações voltadas à orientação das famílias interessadas, divulgação da prática e sua regulamentação, embora já existam grupos locais que se organizam em encontros regulares.

Palavras-chave: Educação domiciliar; direito à educação; socialização.

\section{Introdução}

A educação domiciliar ou homeschooling consiste na prática de famílias não enviarem os filhos para a escola e ensiná-los em casa. No Brasil, tal movimento foi historicamente negado com base no argumento de que as crianças educadas em casa seriam privadas da socialização e formação da cidadania oferecidas pela escola (BARBOSA, 2013). Contudo, pesquisas têm questionado o argumento da escola como único espaço de socialização (ARAI, 1999) e em países da América do Norte as famílias educadoras participam de grupos de apoio locais que propiciam interação e socialização das crianças. Acompanhando tais experiências, muitas famílias brasileiras praticantes da educação domiciliar têm se organizado em grupos em suas regiões. A pesquisa tem como objetivo, portanto, mapear a existência de tais grupos por meio das redes sociais, bem como analisar a divulgação de suas agendas e práticas.

\section{Resultados e Discussão}

A partir do levantamento realizado, foram localizados, pelo facebook, vinte e sete grupos de apoio e mais dois pelo site MeetUp, portal que aproxima pessoas com interesses em comum. Muitos grupos encontrados por estado brasileiro eram derivados da página EducaR (Educação Domiciliar Reformada), como o de Minas Gerais, com cerca de 930 seguidores.

Para além deste, foram encontrados variados grupos de apoio à educação domiciliar em diversos estados e regiões, sendo o de Salvador o maior deles, contando com aproximadamente 1.110 seguidores. Os dois grupos de apoio encontrados através do site MeetUp estão localizados em Santa Catarina e na Amazônia.

A partir da análise, durante um ano, das postagens dos grupos locais de apoio à educação domiciliar que eram abertos ou permitiram o acesso, foi possível constatar que: poucos se organizam em reuniões e encontros objetivando a socialização das crianças; a maioria dos grupos tem as postagens voltadas para divulgação de palestras para pais interessados na educação domiciliar, bem como cursos de formação, atos em prol da prática e orientação dos que tem dúvidas sobre sua regulamentação.
Figura 1. Estados brasileiros que contam com grupos de apoio à educação domiciliar

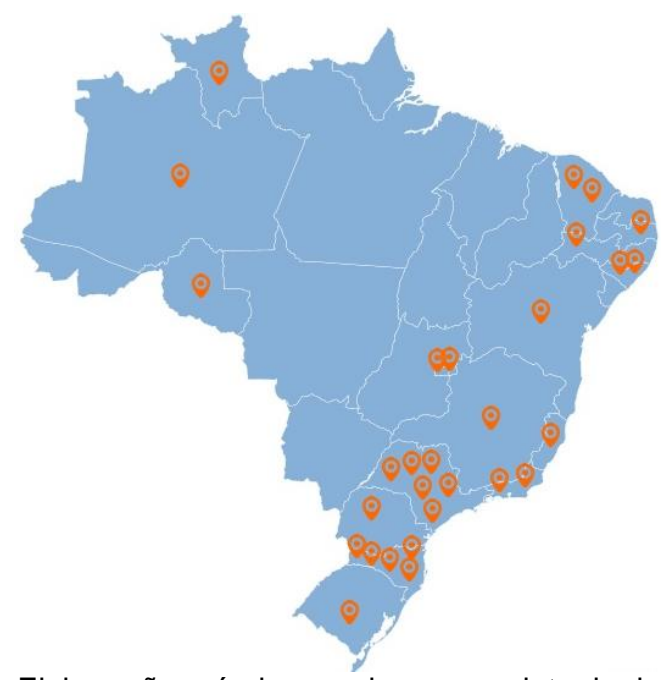

Fonte: Elaboração própria, com base na coleta de dados da pesquisa

\section{Conclusões}

A educação domiciliar no Brasil é um fenômeno crescente e que tem seguido passos da trajetória norte-americana (BARBOSA, EVANGELISTA, 2017), inclusive na criação de grupos de apoio às famílias educadoras.

O mapeamento de tais grupos no Brasil, bem como a análise de suas publicações e postagens durante 0 período da pesquisa, indicou que, por se tratar de movimento recente, estes se encontram em momento de organização, com ações voltadas mais para orientação das famílias e esclarecimentos sobre a prática da educação domiciliar, embora já existam grupos que se organizam em encontros regulares.

\footnotetext{
ARAI, B. Homeschooling and the Redefinition of Citizenship. Education Policy Analysis Archives. v. 7, n. 27, September, 1999.

BARBOSA, L. M. R. Ensino em Casa no Brasil: um desafio à escola? 2013. Tese (doutorado) - Faculdade de Educação, USP, São Paulo, 2013.

BARBOSA, L. M. R.; EVANGELISTA, N. S.. Educação domiciliar e direito à educação: a influência norte-americana no Brasil. EDUCACAO EM PERSPECTIVA, v. 8, p. 1-16, 2017
} 